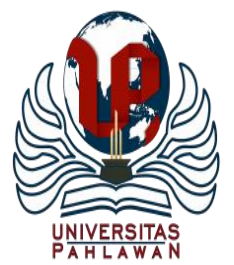

Edukatif : Jurnal Ilmu Pendidikan Volume 3 Nomor 4 Tahun 2021 Halm 2329 - 2338

EDUKATIF: JURNAL ILMU PENDIDIKAN

Research \& Learning in Education

https://edukatif.org/index.php/edukatif/index

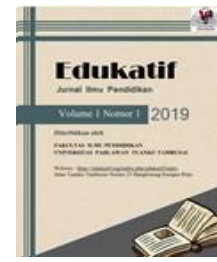

\title{
Pengaruh Pendekatan Saintifik terhadap Hasil Belajar Siswa pada Pembelajaran PAI di Sekolah Dasar
}

\author{
Ichsan Kusaeni $^{1 凶}$, Amirudin ${ }^{2}$, Achmad Junaedi Sittika ${ }^{3}$ \\ Universitas Singaperbangsa Karawang, Indonesia ${ }^{1,2,3}$

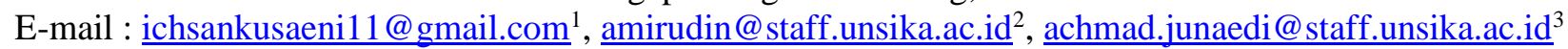

\begin{abstract}
Abstrak
Penelitian ini bertujuan menganalisa dan mendeskripsikan peningkatan hasil belajar dengan menerapkan pendekatan saintifik pada pembelajaran PAI di sekolah dasar. Penelitian merupakan penelitian kuantitatif dengan metode kuasi eksperimen. Desain peneitian menerapkan One Sample Pretest-Posttest Design. Sampel pennelitian sebanyak 30 siswa kelas V SDN Warungbambu I kabupaten Karawang. Instrumen penelitian berupa test sebanyak 30 soal pilihan ganda. Analisis data menggunakan analisis deskriptif, uji normalitas, uji homogenitas, uji beda rata-rata dan uji normalisasi gain. Hasil penelitian diperoleh hasil belajar pretest 72,23 (cukup) dan hasil belajar posttest 81,63 (Baik). uji hipotesis didapatkan bahwa t hitung 0,786 > t tabel 0,683 dengan nilai sig.0,001 <0,05. Hasil analisis menunjukkan bahwa $\mathrm{H}_{0}$ diterima dan $\mathrm{H}_{\mathrm{a}}$ ditolak, dengan demikian terdapat perbedaan rata-rata antara hasil belajar siswa pada tahap pretest dengan tahap posttest. Hasil N-gain menunjukkan bahwa terdapat peningkatan hasil belajar siswa (pretest-posttest) sebesar 9,30 poin dengan nilai normalisasi Gain 0,34. Ini menunjukkan bahwa peningkatan hasil belajar siswa dengan menerapkan pendekatan saintifik pada pembelajaran PAI dalam kategori sedang dengan prosentase $34 \%$.
\end{abstract}

Kata Kunci: Pendekatan Saintifik, Pendidikan Agama Islam, Hasil Belajar.

\begin{abstract}
This study aims to analyze and describe the improvement of learning outcomes by applying a scientific approach to PAI learning in elementary schools. This research is a quantitative research with a quasiexperimental method. The research design applies One Sample Pretest-Posttest Design. The research sample consisted of 30 fifth grade students of SDN Warungbambu I, Karawang district. The research instrument was a test of 30 multiple choice questions. Data analysis used descriptive analysis, normality test, homogeneity test, average difference test and gain normalization test. The results of the study obtained that the pretest learning outcomes were 72.23 (enough) and the posttest learning outcomes were 81.63 (Good). Hypothesis test found that $t$ count $0.786>t$ table 0.683 with sig.0.001 $<0.05$. The results of the analysis show that $H 0$ is accepted and $\mathrm{Ha}$ is rejected, thus there is an average difference between student learning outcomes at the pretest stage and the posttest stage. The results of the $N$-gain show that there is an increase in student learning outcomes (pretest-posttest) of 9.30 points with a normalized value of Gain 0.34. This shows that the increase in student learning outcomes by applying a scientific approach to PAI learning is in the medium category with a percentage of $34 \%$.
\end{abstract}

Keywords: Scientific Approach, Islamic Religious Education, Learning Outcomes.

Copyright (c) 2021 Ichsan Kusaeni, Amirudin, Achmad Junaedi Sittika

$\triangle$ Corresponding author

Email : ichsankusaeni11@gmail.com

DOI : https://doi.org/10.31004/edukatif.v3i4.1134

ISSN 2656-8063 (Media Cetak)

ISSN 2656-8071 (Media Online)

Edukatif : Jurnal Ilmu Pendidikan Vol 3 No 4 Tahun 2021 p-ISSN 2656-8063 e-ISSN 2656-8071 
2330 Pengaruh Pendekatan Saintifik terhadap Hasil Belajar Siswa pada Pembelajaran PAI di Sekolah DasarIchsan Kusaeni, Amirudin, Achmad Junaedi Sittika

DOI: https://doi.org/10.31004/edukatif.v3i4.1134

\section{PENDAHULUAN}

Problematika mutu pembelajaran dan kualitas capaian kompetensi pembelajaran peserta didik, mendorong pemerintah melakukan reformasi pembelajaran (Asmawati \& Bintang Kejora, 2020). Pemerintah melalui Kementerian Pendidikan dan Kebudayaan mengeluarkan kurikulum 2013 menyempurnakan kurikulum sebelumnya yaitu kurikulum KBK tahun 2004 dan kurikulum KTSP tahun 2006 (Rusiyanti, 2016). Pembelajaran yang sebelumnya bersifat teacher centre, dengan kurikulum 2013 pembelajaran diarahkan kepada student centre (Ghozali, 2017; Amirudin \& Muzaki, 2019). Kurikulum 2013 ini dapat mengarahkan siswa ke arah pengembangan kompetensi dan skill yang dibutuhkan di abad 21 (Hosnan, 2014). Guru dituntut lebih kreatif dan inovatif dalam pembelajaran karena guru harus mampu memberdayakan siwa untuk mengembangkan keterampilan kognitif, afektif, psikomotot, dan kemandirian belajar (Zaini, 2015).

Pada pembelajaran PAI di sekolah dasar, dengan diimplementasikannya kurikulum 2013 maka seluruh aspek pembelajaran meliputi perencanaan, pelaksanaan, dan evaluasi di satuan pendidikan harus berbasis saintifik assessment (Rostika, 2019). Pada jenjang sekolah dasar mata pelajaran diarahkan pada pendekatan tematik-integratif (Fadhilaturrahmi, 2017), kecuali beberapa mata pelajaran yang berdiri sendiri seperti Pendidikan Agama Islam (Ritonga, 2017). Temuan (Shunhaji, 2019) mengungkap bahwa Pendidikan Agama Islam dan Budi Pekerti (PAI-BP) di sekolah dasar dirancang dengan pendekatan multidisipliner yang diberikan selama 35 menit kali 4 (empat) jam pertemuan per-pekan.

Pendidikan Agama Islam (PAI) merupakan salah satu mata pelajaran yang ada pada semua jenjang pendidikan (Elkarimah, 2018), mulai dari tingkat sekolah dasar hingga perguruan tinggi yang dapat dijadikan solusi dalam menghadapi persaingan global dan tantangan pendidikan di masa mendatang (Abdul, 2020). PAI memiliki peranan yang sangat penting dalam kehidupan (Andriati et al., 2017). Pendidikan Agama Islam diajaran dengan tujuan meningkatkan keimanan, pemahaman, penghayatan dan pengamalan peserta didik (Amirudin \& Muzaki, 2021) tentang agama Islam sehingga menjadi manusia muslim yang beriman, bertakwa kepada Allah SWT serta berakhlak mulia dalam kehidupan pribadi, berbangsa dan bernegara (Taufik, 2020).

Hasil studi pendahuluan berupa wawancara dan observasi pada pembelajaran PAI di kelas V SDN Warungbambu I, menemukan adanya kelemahan dan kendala dalam pembelajaran PAI yang dapat mempengaruhi hasil belajar siswa. Kelemahan dan kendala yang teridentifikasi antara lain pembelajaran PAI secara konvensioanl yang monoton telah membuat siswa merasa jenuh dalam mengikuti pembelajaran di kelas. Pembelajaran bersifat teacher centre dan kurang menstimulus siswa untuk aktif berdiskusi dan bertanya. Pembelajaran belum diarahkan pada pengembangan keterampilan abad 21 pada siswa seperti berpikir kritis, kolaborasi, kreatif dan komunikatif. Bahkan Ketika guru melakukan ulangan harian, dari 30 peserta didik hanya 12 siswa (40\%) yang lulus KKM, masih terdapat 18 siswa (60\%) yang mendapat hasil belajar ulangan harian di bawah KKM. Berdasarkan hasil studi pendahuluan tersebut, ditemukan faktor yang mengakibatkan peserta didik kurang perhatian dalam penyampaian materi adalah pendekatan pembelajaran yang digunakan dalam proses pembelajaran tidak bervariasi dan tidak efektif sehingga menimbulkan kejenuhan kepada peserta didik sehingga pemahaman menjadi kurang optimal.

Salah satu alternatif solusi untuk menangani permasalahan di atas adalah dengan menerapkan pendekatan yang berfokus pada student centre (Machin, 2014), keterlibatan siswa dalam proses belajar, kemampuan berpikir kritis, dan peningkatan hasil belajar (Permatasari, 2014). Pendekatan saintifik disarankan untuk memperbaiki proses pembelajaran dan meningkatkan hasil belajar PAI siswa. Pembelajaran dengan metode saintifik memiliki karakteristik sebagai berikut: a) berpusat pada siswa, b) melibatkan keterampilan proses sains dalam mengonstruksi konsep, hukum atau prinsip, c) melibatkan proses-proses kognitif yang potensial dalam merangsang perkembangan intelek, khususnya keterampilan berpikir tingkat tinggi siswa, dan d) dapat mengembangkan karakter siswa (Nasir, 2017). 
Pembelajaran dengan pendekatan saintifik memberikan pengaruh positif bagi guru dan siswa (Amirudin et al., 2020), karena pembelajarannya mengacu pada proses berpikir ilmiah yang melatih pemikiran sistematis dan holistik. Pendekatan saintifik tidak hanya melihat belajar sebagai muara tetapi lebih membangun keterkaitan interkoneksi pengetahuan yang tercermin dalam keterampilan proses, untuk mengeksplorasi dan mengelaborasi materi pelajaran, di samping itu memberikan kesempatan seluas-luasnya bagi guru untuk menggali pengetahuan siswa sesuai dengan kemampuan dan kebutuhan peserta didik (Nasir, 2017).

Fidya et al (2018) dalam penelitiannya menjelaskan bahwa pendekatan saintifik mampu meningkatkan hasil belajar siswa. Penelitian Chintiyatmi et al (2013) mengemukakan pengaruh pendekatan saintifik terhadap hasi belajar siswa dalam pembelajaran PAI SD adalah sebesar 22,56\%. Temuan Muhamad Ansori (2020) dalam penelitiannya menemukan bahwa pengaruh pendekatan saintifik terhadap Prestasi belajar siswa pada mata pelajaran pendidikan agama Islam di skeolah dasar adalah 96,04\% . Dari beberapa penelitian di aats menunjukkan pendekatan saintifik berpengaruh pada peningkatan hasil belajar siswa pada pembelajaran PAI di sekolah dasar.

Penelitian mengenai pengaruh pendekatan saintifik terhadap hasil belajar telah banyak dilakukan, Namun umumnya diterapkan dalam penelitian pembelajaran sains. Diakui bahwa ada pula penelitian penerapan pendekatan saintifik dalam pembelajaran PAI di sekolah dasar, namun umumnya lebih kepada studi korelatif dan survei. Sedangkan pada penelitian kali ini, penelitian akan menggambarkan seberapa besar peningkatan hasil belajar PAI dengan penerapan pendekatan saintifik melalui studi eksperimen sehingga akan mampu menghasilkan sebuah penelitiian yang empiris dan ilmiah.

Penelitian ini penting dilakukan untuk mengatasi masalah rendahnya hasil belajar siswa sekolah dasar dalam pembelajaran PAI. Ini dilatarbelakangi berdasarkan tujuan pembelajaran PAI yang berdampak besar bagi proses kehidupan siswa sekolah dasar dalam memecahkan masalah sehari-hari. Untuk membuktikan dan sekaligus mengatasi permasalahan yang dihadapi mengenai rendahnya hasil belajar sekolah dasar mahasiswa, perlu dilakukan penelitian dan studi eksperimental lebih mendalam. Pendekatan saintifik sebagai sebuah solusi dalam mengatasi permasalahan pembelajaran pada kuikulum 2013 perlu diteliti kebermanfaatannya. Tujuannya adalah untuk mengetahui metode yang tepat dan peningkatan hasil belajar yang terjadi melalui pembelajaran saintifik pada pembelajaran PAI di sekolah dasar.

\section{METODE PENELITIAN}

Penelitian ini merupakan penelitian kuantitatif dengan metode eksperimen kuasi (Quasi Experimental) atau biasa juga disebut eksperimen semu (Sugiyono, 2016). Dengan metode kuasi eksperimen, sampel dan kelas yang dipilih bersifat alamiah tanpa rekayasa (Kejora, 2020). Selain itu pemiihan kuasi eksperimen karena berbagai hal, terutama berkenaan dengan pengontrolan variabel, kemungkinan sukar sekali jika digunakan eksperimen murni (Creswell, 2014). Adapun dikarenakan keterbatasan populasi dan sampel, penelitian eksperimen ini menggunakan desain One Group Pretest-Posttest Design dimana penelitian hanya dilakukan pada kelas eksperimen tanpa adanya kelas control (Asmawati \& Bintang Kejora, 2020).

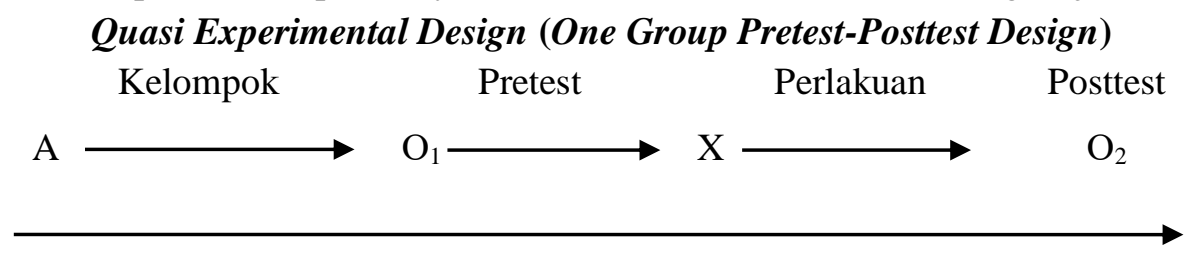

Gambar 1. Desain Penelitian

Keterangan:

$\mathrm{A}=$ Subyek kelompok eksperimen

$\mathrm{X}=$ Perlakuan (pembelajaran PAI meneraokan pendekatan saintifik). 
2332 Pengaruh Pendekatan Saintifik terhadap Hasil Belajar Siswa pada Pembelajaran PAI di Sekolah DasarIchsan Kusaeni, Amirudin, Achmad Junaedi Sittika

DOI: https://doi.org/10.31004/edukatif.v3i4.1134

$\mathrm{O}_{1}=$ Tes sebelum ada perlakuan menggunakan pendekaatn saintifik.

$\mathrm{O}_{2}=$ Tes setelah ada perlakuan menggunakan pendekaatn saintifik.

Penelitian eksperimen melibatkan sampel 30 siswa kelas V SDN Warungbambu I kabupaten Karawang. Pengumpulan data menggunakan tes sebanyak 30 soal. Materi yang diangkat adalah pada (KD 6.1. Membaca Q.S Al Maun dan Al-Fiil. dan mengartikan Q.S Al-Maun dan Al-Fiil). Kisi-kisi instrument sebgai berikut:

Tabel 1. Kisi-Kisi Instrumen

\begin{tabular}{cll}
\hline Kompetensi Dasar & \multicolumn{1}{c}{ Materi Pokok } & \multicolumn{1}{c}{ Indikator } \\
\hline & & 6.1 .1 Membaca QS. Al-Maun \\
6.1. Membaca QS Al Maun dan & Membaca Q.S. Al-Maun & 6.1 .2 Menyebutkan QS. Al-Maun \\
Al-Fiil. dan mengartikan QS & & 6.1 .3 Menjelaskan QS. Al-Maun \\
\cline { 2 - 3 } Al-Maun dan Al-Fiil & & 6.1 .4 Membaca QS. Al-Fiil \\
& Membaca Q.S. Al-Fiil. & 6.1.5 Menyebutkan QS. Al-Fiil \\
& & 6.1 .6 Menjelaskan QS. Al-Fiil. \\
\hline
\end{tabular}

Data hasil tes siswa dianalisis dengan bantuan aplikasi SPSS (Statistical Package of Social Science). secara deskriptif, Dengan bantuan software SPSS dapat diperoleh perhitungan statistik deskriptif seperti mean, median, modus, deviasi standar, skor minimum, skor maksimum,uji persyaratan analisis (uji normalitas dan uji homogenitas), distribusi frekuensinya, dan uji hipotesis dengan uji beda rata-rata (Septiani \& Kejora, 2021). Untuk keperluan evaluasi, ditentukan pedoman penskoran/penilaian dengan KKM (kriteria ketuntasan minimal) pada nilai 70 .

Tabel 2. Interprestasi Penilaian

\begin{tabular}{lccc}
\hline No & Rentang & Keterangan & Simbol Huruf \\
\hline 1. & $<70$ & Kurang & D \\
\hline 2. & $70,00-79,99$ & Cukup & C \\
\hline 3. & $80,00-89,99$ & Baik/Tinggi & B \\
\hline 4. & $90,00-100$ & Sangat Baik/Sangat Tinggi & A \\
\hline
\end{tabular}

Selanjutnya untuk mengetahui besarnya peningkatan kreativitas anak dalam membuat kolase digunakan rumus $N$-gain sebagai berikut:

$$
\begin{aligned}
& \langle\mathrm{g}\rangle=\frac{(\text { s post }-S \text { Pre })}{(\text { s mid }-S \text { Pre })} \\
& \text { keterangan : } \\
& \mathrm{g} \quad=\text { rata-rata skor gain dinormalisasi } \\
& \mathrm{S}_{\text {post }}=\text { skor } \text { posttest } \\
& \mathrm{S}_{\text {pre }}=\text { skor } \text { pretest } \\
& \mathrm{S}_{\text {mid }}=\text { skor maksimal ideal }
\end{aligned}
$$

Kemudian nilai g dikonsultasikan ke dalam tabel 3.8 untuk diinterpretasi.

Tabel 3. Pedoman Interprestasi Nilai N-gain

\begin{tabular}{cc}
\hline Interval N-gain & Katagori \\
\hline $\mathrm{g}<0.3$ & Rendah \\
\hline $0.3 \leq \mathrm{g} \leq 0.7$ & Sedang \\
\hline $\mathrm{g}>0.7$ & Tinggi \\
\hline
\end{tabular}


2333 Pengaruh Pendekatan Saintifik terhadap Hasil Belajar Siswa pada Pembelajaran PAI di Sekolah DasarIchsan Kusaeni, Amirudin, Achmad Junaedi Sittika

DOI: https://doi.org/10.31004/edukatif.v3i4.1134

\section{HASIL DAN PEMBAHASAN PENELITIAN}

Pembelajaran PAI dengan pendekatan santifik dilaksanakan dalam 3 pertemuan tatap muka. Langkah Langkah pembelajaran dalam penelitiaan eksperimen di kelas V SDN Warungbambu I sebagai berikut:

\section{Kegiatan awal:}

1) Pendidik membuka pelajaran dengan salam dilanjutkan dengan berdoa, kemudian menanyakan peserta didik yang tidak hadir.

2) Apersepsi yaitu pendidik memberikan kesempatan kepada peserta didik untuk mengingat-ngingat dan kemudian pendidik menceritakan pengalaman yang tidak terlupakan yang berkaitan dengan materi yang telah disampaikan dan materi yang akan disampaikan yaitu tentang surat Al-Maun atau Al- Fiil.

3) Pendidik menyampaikan tujuan pembelajaran dan pokok-pokok materi yang akan dipelajari.

4) Memotivasi peserta didik dengan memberikan dorongan untuk mempelajari materi pelajaran dengan baik dengan mengaitkan pengalaman-pengalaman yang telah diungkapkan oleh salah satu peserta didik.

\section{Kegiatan inti:}

\section{1) Mengamati}

a) Pendidik membagi beberapa peserta didik menjadi lima kelompok dan ketua kelompok memilih materi apa yang akan diambil untuk didiskusikan bersama teman sekelompoknya.

b) Pendidik bercerita sebentar tentang asbabul nuzul dari materi yang akan disampaikan yaitu surat AlMaun dan Al-Fiil.

c) Pendidik menginstruksikan kepada setiap kelompok untuk membaca materi yang sudah disediakan oleh pendidik yaitu surat Al-Maun atau Al- Fiil. kemudian didiskusikan bersama teman sekelompoknya membahas apa isi pokok dari surat Al-Maun atau Al- Fiil tersebut.

d) Pendidik memberikan kesempatan kepada salah satu peserta didik untuk menceritakan pengalamannya yang berhubungan dengan Al-Maun dan Al- Fiil.

\section{2) Menanya}

Pendidik memberikan kesempatan kepada peserta didik untuk menggali pengetahuan awal terhadap materi yang akan diajarkan berupa pertanyaan untuk menggugah rasa ingin tahu kepada peserta didik yang berkaitan dengan surat Al-Maun dan Al-Fiil. salah satu diantaranya yaitu:

a. kenapa surat itu termasuk surat makiyah?

b. Apa inti yang bisa diambil dari surat tersebut ?

c. Apa yang diceritakan berdasarkan isi kandungan ayat dari surat tersebut?

d. Apa makna dari Al-Ma'un dan Al-fil?

\section{Menalar}

Peserta didik dibawah bimbingan pendidik berusaha menemukan jawaban dari beberapa pertanyaan dan masalah yang diajukan.

\section{Eksperimen}

a) Peserta didik berdiskusi sesama rekan satu kelompoknya.

b) Peserta didik saling mengajukan beberapa pertanyaan dan jawaban dikelas.

c) Pendidik berkeliling untuk mengamati, memotivasi, dan memfasilitasi kerja sama tersebut agar berjalan dengan tertib dan lancar.

d) Setiap peserta didik berinteraksi dengan peserta didik lain untuk memberi dan menerima pengetahuan dan pengalaman baru tentang materi yang dibahas tentang surat Al-Maun dan Al- Fiil.

\section{Mengkomunikasikan}

a) Apabila Peserta didik sudah mengetahui isi pokok dari surat tersebut, pendidik meminta peserta didik bekerja sama dalam kelompoknya untuk menyelesaikan permasalahan yang diajukan pendidik yaitu penugasan masing-masing peserta didik menceritakan pengalamannya dikelompoknya masing-masing, kemudian menyimpulkan pengalamannya tersebut yang berkaitan dengan Al-Maun atau Al- Fiil. 
2334 Pengaruh Pendekatan Saintifik terhadap Hasil Belajar Siswa pada Pembelajaran PAI di Sekolah DasarIchsan Kusaeni, Amirudin, Achmad Junaedi Sittika

DOI: https://doi.org/10.31004/edukatif.v3i4.1134

b) Perwakilan dari peserta didik pada tiap kelompok untuk mempresentasikan hasil diskusi dan kelompok yang lain menanggapi hasil kerjanya tersebut.

c) Pendidik memfasilitasi apabila terdapat permasalahan yang dianggap sulit.

d) Dengan mengacu pada jawaban peserta didik, melalui tanya jawab, pendidik dan peserta didik membahas cara penyelesaian masalah yang tepat.

\section{c) Kegiatan Penutup}

1) Pendidik mengadakan refleksi tentang pengalaman belajar peserta didik.

2) Pendidik meminta kepada peserta didik untuk menulis rangkuman tentang surat Al-Maun dan surat Al- Fiil.

3) Pendidik bersama peserta didik bertanya jawab meluruskan kesalahan pemahaman, memberikan penguatan dan penyimpulan.

4) Memberikan penghargaan berupa up lose kepada kelompok yang baik ketika berdiskusi dan bertanya jawab.

5) Pendidik memfasilitasi jika ada materi yang belum dipahami dengan baik oleh peserta didik serta kesan dan pesan selama mengikuti pembelajaran.

6) Peserta didik mengerjakan lembar tugas

7) Peserta didik menukarkan lembar tugas satu dengan yang lain, kemudian, pendidik bersama peserta didik membahas penyelesaian lembar tugas dan sekaligus dapat memberi nilai pada lembar tugas sesuai kesepakatan yang telah diambil (ini dapat dilakukan apabila waktu masih tersedia).

Sebelum diberikan treatment pembelajaran saintifik, siswa diberikan tes (pre-test) untuk mengetahui hasil belajar awal siswa. Kemudian dilaksanakan pembelajaran selama 3 tatap muka sebagaimana dijelaskan sebelumnya. Setelah itu, dilaksanakan post-test untuk mengetahui hasil belajar siswa setelah diberikan treatment. Hasil belajar siswa digambarkan sebaagi berikut:

Tabel 4. Hasil Belajar Siswa

\begin{tabular}{cccccc}
\hline No & Identitas & Pretest & Interprestasi & Posttest & Interprestasi \\
\hline 1 & Eks_1 & 70 & Cukup & 87 & Baik \\
\hline 2 & Eks_2 & 67 & Kurang & 73 & Cukup \\
\hline 3 & Eks_3 & 60 & Kurang & 70 & Cukup \\
\hline 4 & Eks_4 & 77 & Cukup & 77 & Cukup \\
\hline 5 & Eks_5 & 47 & Kurang & 83 & Baik \\
\hline 6 & Eks_6 & 87 & Baik & 87 & Baik \\
\hline 7 & Eks_7 & 87 & Baik & 80 & Baik \\
\hline 8 & Eks_8 & 70 & Cukup & 80 & Baik \\
\hline 9 & Eks_9 & 67 & Kurang & 83 & Baik \\
\hline 10 & Eks_10 & 67 & Kurang & 80 & Baik \\
\hline 11 & Eks_11 & 63 & Cukup & 77 & Cukup \\
\hline 12 & Eks_12 & 83 & Baik & 93 & Sangat Baik \\
\hline 13 & Eks_13 & 77 & Cukup & 90 & Sangat Baik \\
\hline 14 & Eks_14 & 67 & Kurang & 83 & Baik \\
\hline 15 & Eks_15 & 63 & Kurang & 80 & Baik \\
\hline 16 & Eks_16 & 73 & Cukup & 77 & Cukup \\
\hline 17 & Eks_17 & 60 & Kurang & 83 & Baik \\
\hline 18 & Eks_18 & 70 & Cukup & 88 & Baik \\
\hline 19 & Eks_19 & 70 & Cukup & 83 & Baik \\
\hline 20 & Eks_20 & 77 & Cukup & 80 & Baik \\
\hline 21 & Eks_21 & 87 & Baik & 80 & Baik \\
\hline 22 & Eks_22 & 83 & Baik & 87 & Baik \\
\hline 23 & Eks_23 & 87 & Baik & 80 & Baik \\
\hline 24 & Eks_24 & 77 & Cukup & 91 & Sangat Baik \\
\hline & & & & &
\end{tabular}


2335 Pengaruh Pendekatan Saintifik terhadap Hasil Belajar Siswa pada Pembelajaran PAI di Sekolah Dasar Ichsan Kusaeni, Amirudin, Achmad Junaedi Sittika

DOI: https://doi.org/10.31004/edukatif.v3i4.1134

\begin{tabular}{cccccc}
\hline No & Identitas & Pretest & Interprestasi & Posttest & Interprestasi \\
\hline 25 & Eks_25 & 67 & Cukup & 80 & Baik \\
\hline 26 & Eks_26 & 77 & Cukup & 63 & Kurang \\
\hline 27 & Eks_27 & 50 & Kurang & 60 & Cukup \\
\hline 28 & Eks_28 & 70 & Cukup & 86 & Baik \\
\hline 29 & Eks_29 & 87 & Baik & 93 & Sangat Baik \\
\hline 30 & Eks_30 & 87 & Baik & 94 & Sangat Baik \\
\hline & Rata-Rata & 72,23 & Cukup & 81,63 & Baik \\
\hline
\end{tabular}

Berdasarkan data hasil belajar siswa diperoleh gambaran pada tahap pretest hasil belajar siswa rata-rata 72,23 pada kriteria CUKUP dan berada di atas KKM 70. Kemudian dilakukan treatment pembelajaran PAI dengan pendekatan saintifik dan diperoleh hasil belajar siswa rata-rata 81,63 pada kriteria BAIK dan berada di atas KKM 70. Untuk mengetahui perbedaan hasil belajar siswa berdasarkan kelulusan KKM pada posttest dan posttetst dilaporkan sebagai berikut:

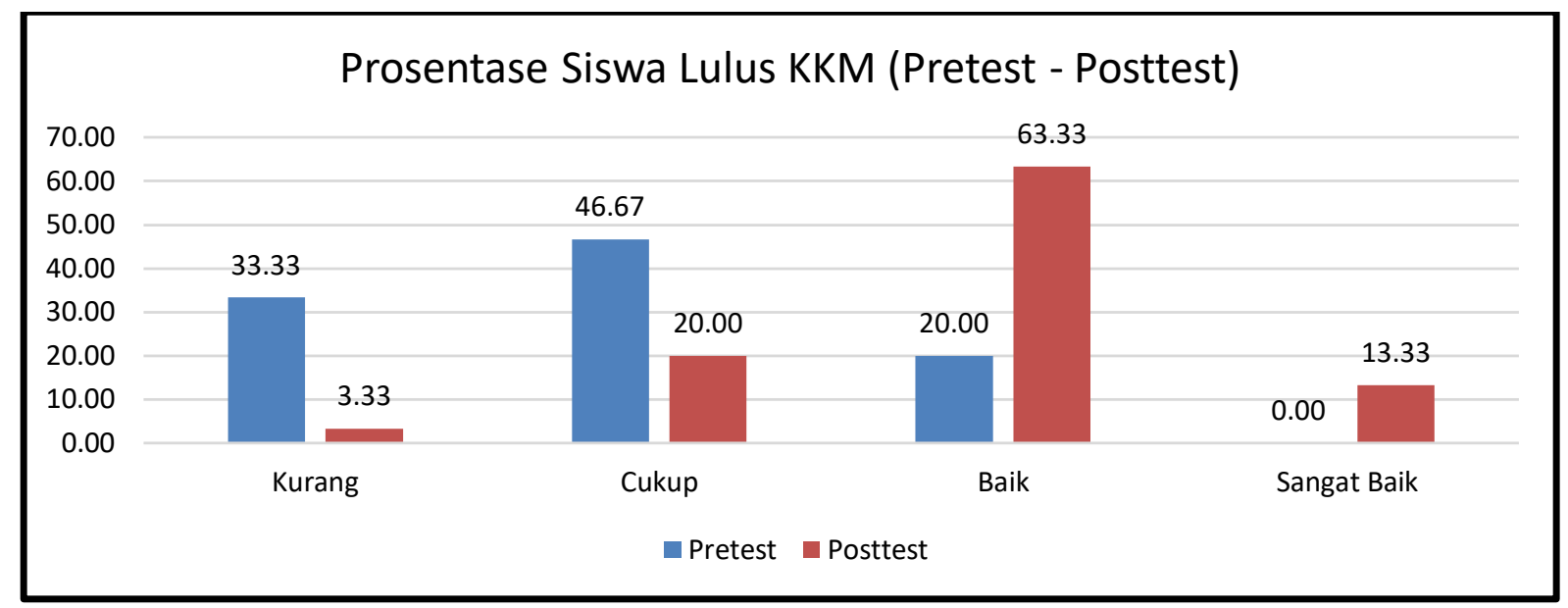

Gambar 2. Prosentase Siswa Lulus KKM

Berdasarkan data jumlah siswa yang lulus KKM, pada pretest terdapat 10 siswa $(33,3 \%)$ dalam kategori kurang dan tidak lulus KKM, 14 siswa (46,67\%) dalam kategori cukup, 6 siswa (20\%) dalam kategori baik, dan tidak ada satupun siswa yang memeproleh nilai sangat baik. Sedangkan pada posttest hanya terdapat 1 siswa (3,33\%) yang tidak lulus KKM, 6 siswa (20\%) dalam kategori cukup, 19 siswa (63,33\%) dalam kategori baik, dan 4 siswa $(13,33 \%)$ dalam kategori sangat baik. Dengan demikian terdapat peningkatan kualitas belajar siswa yang ditunjukkan oleh lebih banyaknya siswa yang lolos KKM.

Untuk mengetahui signifikansi peningkatan hasil belajar siswa pada pembelajaran PAI menerapkan pendekatan saintifik, perlu dilakukan uji hipotesis menggunaan uji beda rata-rata (Paired Sample T-Test) berbantuan SPSS. Hasilnya sebaagi berikut:

Tabel 5. Uji Hipotesis

\begin{tabular}{ccccccc}
\hline Keterangan & $\begin{array}{c}\text { Uji } \\
\text { Normalitas }\end{array}$ & Keputusan & $\begin{array}{c}\text { Uji } \\
\text { Homogenitas }\end{array}$ & Keputusan & T $_{\text {hitung }}$ & $\begin{array}{c}\text { Sig (2- } \\
\text { tailed) }\end{array}$ \\
\cline { 1 - 3 } Pretest & 0,396 & Normal & 0,262 & Homogen & 0,786 & 0,001 \\
\cline { 1 - 3 } Posttest & 0,066 & Normal & 0,262 & &
\end{tabular}

Berdasarkan uji hipotesis didapatkan bahwa t hitung 0,786 > t tabel 0,683 dengan nilai sig.0,001 <0,05. Hasil analisis menunjukkan bahwa $\mathrm{H}_{0}$ diterima dan $\mathrm{H}_{\mathrm{a}}$ ditolak, dengan demikian terdapat perbedaan rata-rata antara hasil belajar siswa pada tahap pretest dengan tahap posttest. Jika kita melihat secara kuantittaif besarnya nilai posttest $(81,63)$ lebih besar daripada nilai pretest $(72,23)$. Maka dapat disimpulkan bahwa 
2336 Pengaruh Pendekatan Saintifik terhadap Hasil Belajar Siswa pada Pembelajaran PAI di Sekolah DasarIchsan Kusaeni, Amirudin, Achmad Junaedi Sittika

DOI: https://doi.org/10.31004/edukatif.v3i4.1134

penerapan pendekatan saintifik mampu meningkatkan hasil belajar siswa pada mata pelajaran PAI kelas $\mathrm{V}$ di SDN Warungbambu I.

Selanjutnya untuk mengetahui seberapa besar peningkatan pretest ke posttest dilakukan uji normalisasi dengan formula N-Gain, hasilnya dilaporkan sebabai berikut:

Tabel 6. N-Gain

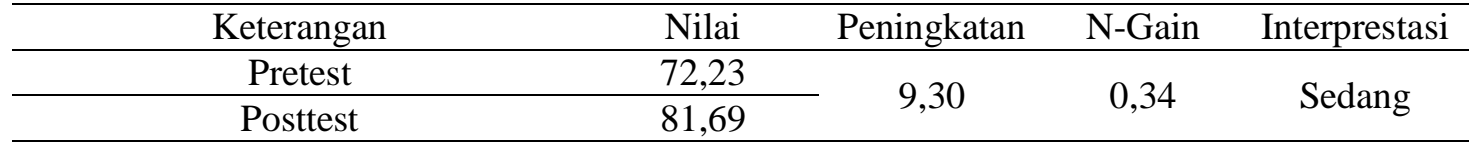

Hasil N-gain menunjukkan bahwa terdapat peningkatan hasil belajar siswa sebesar 9,30 poin dengan nilai normalisasi Gain 0,34. Ini menunjukkan bahwa peningkatan hasil belajar siswa dengan menerapkan pendekatan saintifik pada pembelajaran PAI dalam kategori sedang. N-gain 0,34 menunjukkan besarnya pengaruh berupa peningkatan sebesar $34 \%$.

Penelitian Rusiyanti (2016) menjelaskan penerapan pendekatan saintifik berpengaruh pada peningkatan prestasi belajar sebesar 94,1\%. (Fidya et al., 2018) meneliti dengan penelitian tindakan kelas menemukan hasil belajar siswa di kelas eksperimen meningkat dari nilai rata- rata hasil pretes siswa sebesar 17.97 meningkat menjadi 79.48 pada hasil postes. Penelitian Erny et al (2017) menemukan pendekatan saintifik efektif meningkatkan hasil belajar sebesar 97,5\%. Dengan demikian hasil penelitian ini menguatkan dan sejalan dengan penelitian sebelumnya yang menyatakan bahwa pendekatan saintifik efektif dalam meningkatkan hasil belajar peserta didik. Namun yang membedakan adalah tingkat prosesntase peningkatannya. Penting bagi guru memperhatikan faktor-faktor yang mendukung peningkatan belajar siswa seperti media yang digunakan, gaya mengajar, iklim belajar, lingkungan yang kondusif, motivasi belajar, kemandirian belajar siswa, dan evaluasi yang digunakan.

\section{KESIMPULAN}

Pembelajaran PAI dengan menerapkan pendekatan saintifik efektif dalam meningkatkan hasil belajar siswa kelas V SDN Warungbambu I kabupaten Karawang. Hasil belajar pretest siswa rata-rata rata 72,23 dengan sebanyak 10 siswa $(33,3 \%)$ dalam kategori kurang dan tidak lulus KKM, 14 siswa (46,67\%) dalam kategori cukup, 6 siswa (20\%) dalam kategori baik, dan tidak ada satupun siswa yang memeproleh nilai sangat baik. Hasil belajar posttets siswa rata-rata 81,63 dengan sebanyak 1 siswa $(3,33 \%)$ yang tidak lulus KKM, 6 siswa (20\%) dalam kategori cukup, 19 siswa (63,33\%) dalam kategori baik, dan 4 siswa $(13,33 \%)$ dalam kegori sangat baik. Hasil uji hipotesis didapatkan bahwa t hitung 0,786>t tabel 0,683 dengan nilai sig.0,001< 0,05. Hasil analisis menunjukkan bahwa $\mathrm{H}_{0}$ diterima dan $\mathrm{H}_{\mathrm{a}}$ ditolak, dengan demikian terdapat peningkatan hasil belajar. Nilai N-Gain 0,34 menggambarkan bahwa terdapat peningkatan hasil belajar siswa dengan menerapkan pendekatan saintifik pada pembelajaran PAI dalam kategori sedang dengan prosentase $34 \%$.

\section{DAFTAR PUSTAKA}

Abdul, D. (2020). Pemanfaatan Media Digital Dalam Pembelajaran Pai. Al-Bahtsu, 5(2), $76-81$. Https://Ejournal.Iainbengkulu.Ac.Id/Index.Php/Albahtsu/Article/View/3376

Amirudin, A., \& Muzaki, I. A. (2019). Life Skill Education And It'S Implementation In Study Programs Islamic Religious Education. Jurnal Tarbiyah, 26(2), 278-293. Https://Doi.Org/10.30829/Tar.V26i2.485

Amirudin, \& Muzaki, I. A. (2021). Demonstration Of Effectiveness Of Implementation Method Of Student Learning Prayers. Ta'dib. Jurnal Pendidikan Islam, 10(1), 111-120. Https://Doi.Org/10.29313/Tjpi.V10i1.7816 
2337 Pengaruh Pendekatan Saintifik terhadap Hasil Belajar Siswa pada Pembelajaran PAI di Sekolah DasarIchsan Kusaeni, Amirudin, Achmad Junaedi Sittika

DOI: https://doi.org/10.31004/edukatif.v3i4.1134

Amirudin, Nurlaeli, A., \& Amar Muzaki, I. (2020). Pengaruh Metode Reward And Punishment Terhadap Hasil Belajar Siswa Pada Bidang Studi Pendidikan Agama Islam (Studi Kasus Di SDIT Tahfizh Qur'an Al-Jabar Karawang). TARBAWY: Indonesian Journal Of Islamic Education, 7(2), 140. Https://Doi.Org/10.17509/T.V7i2.26102

Andriati, I., Sesmiarni, Z., \& Armanida. (2017). Implementasi Pendekatan Scientific Pada Mata Pelajaran Pendidikan Agama Islam Di Sekolah Dasar. Jurnal Educative : Journal Of Educational Studies, 2(2).

Asmawati, E., \& Bintang Kejora, M. T. (2020). The Effect Of Using Simple Aircraft Concrete Media On The Mastery Of Concepts In Inquiry Science Learning In Elementary School Students. Mudarrisa: Jurnal Kajian Pendidikan Islam, 12(2), 150-168. Https://Doi.Org/10.18326/Mdr.V12i2.150-168

Chintiyatmi, I. T., Nurlela, \& Mahfud. (2013). Pengaruh Penerapan Pendekatan Scientific Terhadap Hasil Belajar Pada Mata Pelajaran Pendidikan Agama Islam Siswa Kelas Viii Sekolah Menengah Pertama (Smp) Negeri 7 Kota Cirebon. Jurnal At Tarbawi Al Haditsah, 1(2), 1-26.

Creswell, J. W. (2014). Research Design Qualitative, Quantitative, And Mixed Method Approaches. Sage Publication. Inc.

Elkarimah, M. F. (2018). Penerapan Saintifik Pada Pembelajaran Pendidikan Agama Islam (SD Islam Bina Insani Muslim Bekasi). SAP (Susunan Artikel Pendidikan), 3(1), 69-77. Https://Doi.Org/10.30998/Sap.V3i1.2740

Erny, Haji, S., \& Widada, W. (2017). Pengaruh Pendekatan Saintifik Pada Pembelajaran Matematika Terhadap Kemampuan Pemecahan Masalah Dan Kemampuan Berpikir Tingkat Tinggi Siswa Kelas X IPA SMA Negeri 1 Kepahiang. Jurnal Pendidikan Matematika Raflesia, 2(1), 165-173.

Fadhilaturrahmi, F. (2017). Penerapan Pendekatan Saintifik Untuk Meningkatkan Kemampuan Komunikasi Matematik Peserta Didik Di Sekolah Dasar. Eduhumaniora|Jurnal Pendidikan Dasar Kampus Cibiru, 9(2), 109. Https://Doi.Org/10.17509/Eh.V9i2.7078

Fidya, F., Sihaloho, M., \& Botutihe, D. N. (2018). Pengaruh Penggunaan Pendekatan Saintifik Terhadap Hasil Belajar Siswa Pada Materi Hidrolisis Garam. Jambura Journal Of Educational Chemistry, 13(2), 143149.

Ghozali, I. (2017). Pendekatan Scientific Learning Dalam Meningkatkan Prestasi Belajar Siswa. Jurnal Pedagogik, 04(01), 1-13.

Hosnan, M. (2014). Pendekatan Saintifik Dan Kontekstual Dalam Pembelajaran Abad 21. Ghalia Indonesia.

Kejora, M. T. B. (2020). The Use Of Concrete Media In Science Learning In Inquiry To Improve Science Process Skills For Simple Machine Subject. MUDARRISA: Jurnal Kajian Pendidikan Islam, 12(1), 117. Https://Doi.Org/10.18326/Mdr.V12i1.1-17

Machin, A. (2014). Implementasi Pendekatan Saintifik, Penanaman Karakter Dan Konservasi Pada Pembelajaran Materi Pertumbuhan. Jurnal Pendidikan IPA Indonesia, 3(1), 28-36. Http://Journal.Unnes.Ac.Id/Nju/Index.Php/Jpii\%0aliterasi

Muhamad Ansori. (2020). Pengaruh Pendekatan Saintifik Terhadap Prestasibelajar Siswapada Mata Pelajaran Pendidikan Agama Islam. Al Qodiri: Jurnal Pendidikan, Sosial Dan Keagamaan, 18(1), 100. Www.Journal.Uta45jakarta.Ac.Id

Nasir, R. (2017). Implementation Of Scientific Approach To Enhance. 5(October), 356-363.

Permatasari, E. P. (2014). Implementasi Pendekatan Saintifik Dalam Kurikulum 2013 Pada Pembelajaran Sejarah. Indonesian Journal Of History Education, 3(1), 11-16.

Ritonga, A. A. (2017). Pendekatan Saintifik Pembelajaran Pendidikan Agama Islam Pada Sekolah Dasar Islam Terpadu. MIQOT: Jurnal Ilmu-Ilmu Keislaman, 41(1), $78-97$. Https://Doi.Org/10.30821/Miqot.V41i1.339

Rostika, D. (2019). Pemahaman Guru Tentang Pendekatan Saintifik Dan. Eduhumaniora | Jurnal Pendidikan 
2338 Pengaruh Pendekatan Saintifik terhadap Hasil Belajar Siswa pada Pembelajaran PAI di Sekolah DasarIchsan Kusaeni, Amirudin, Achmad Junaedi Sittika

DOI: https://doi.org/10.31004/edukatif.v3i4.1134

Dasar, 11(1), 86-94. Http://Ejournal.Upi.Edu/Index.Php/Eduhumaniora/Article/View/14443/Pdf

Rusiyanti, E. (2016). Pengaruh Pendekatan Saintifik Terhadap Prestasi Belajar Siswa Pada Mata Pelajaran Ips Kelas Viii E Di Smp Negeri 24 Surabaya. Avatara, 4(3), 1247-1259.

Septiani, A., \& Kejora, M. T. B. (2021). Edukatif: Jurnal Ilmu Pendidikan Tingkat Aktivitas Belajar Siswa Pada Pembelajaran Online Pendidikan Agama Islam Di Masa. 3(5), 2594-2606.

Shunhaji, A. (2019). Agama Dalam Pendidikan Agama Islam Di Sekolah Dasar. Andragogi: Jurnal Pendidikan Islam Dan Manajemen Pendidikan Islam, 1(1), 1-22. Https://Doi.Org/10.36671/Andragogi.V1i1.46

Sugiyono. (2016). Metode Penelitian Kombinasi (Mix Methode). Alfabeta.

Taufik, M. (2020). Strategic Role Of Islamic Religious Education In Strengthening Character Education In The Era Of Industrial Revolution 4.0. Jurnal Ilmiah Islam Futura, 20(1), 86. Https://Doi.Org/10.22373/Jiif.V20i1.5797

Zaini, H. (2015). Karakteristik Kurikulum 2013 Dan Kurikulum Tingkat Satuan Pendidikan (Ktsp). Idaroh, $1(01), 15-31$. 